\section{Paracetamol lindrer ikke ryggsmerter}

Paracetamol gir lite smertelindring ved hofteartrose, kneartrose og uspesifikke ryggsmerter. Dette viser en ny metaanalyse.

Paracetamol er førstevalget i smertelindring ved rygg- og nakkesmerter og artrose $i$ hofte og kne, men kunnskapsgrunnlaget er usikkert.

I en metaanalyse inngikk randomiserte studier der man sammenliknet effekten av paracetamol med placebo $(n=13)$. Analysen viste at paracetamol verken reduserte smerteintensitet eller funksjonsnedsettelse eller forbedret livskvalitet hos pasienter med uspesifikke korsryggssmerter på kort sikt. Ved artrose i hofte eller kne hadde paracetamol en liten, men klinisk ubetydelig effekt på smerte og funksjonsnivå på kort sikt. Andel rapporterte uønskede hendelser var lik i paracetamolgruppen som i placebogruppen.

- Denne metaanalysen viser at paracetamol alene ikke gir tilstrekkelig lindring hos de fleste pasientene med disse smertetilstandene, sier professor Olav M. Fredheim ved Nasjonal kompetansetjeneste for sammensatte lidelser ved Norges teknisknaturvitenskapelige universitet. Studien omfatter imidlertid ikke bruken av paracetamol i multimodale smerteregimer.

Studien er en påminnelse om at paracetamol ofte ikke gir tilstrekkelig effektiv smertelindring ved moderate til sterke smerter, og at ikke-medikamentelle behandlingsmåter kan være vel så effektive som medikamenter. Det er viktig å evaluere effekten av analgetika for å vurdere om man må supplere med andre analgetika, seponere eller sette i verk flere ikke-medikamentelle behandlingstiltak, påpeker Fredheim.

\section{Trine B. Haugen}

Tidsskriftet

\section{Litteratur}

1. Machado GC, Maher CG, Ferreira PH et al. Efficacy and safety of paracetamol for spinal pain and osteoarthritis: systematic review and meta-analysis of randomised placebo controlled trials. BMJ 2015; 350: h1225.

\title{
Variabel effekt av A-vitamin til nyfødte
}

\author{
Tre store studier designet for å vurdere effekt av A-vitamintilskudd \\ til nyfødte viser varierende resultater.
}

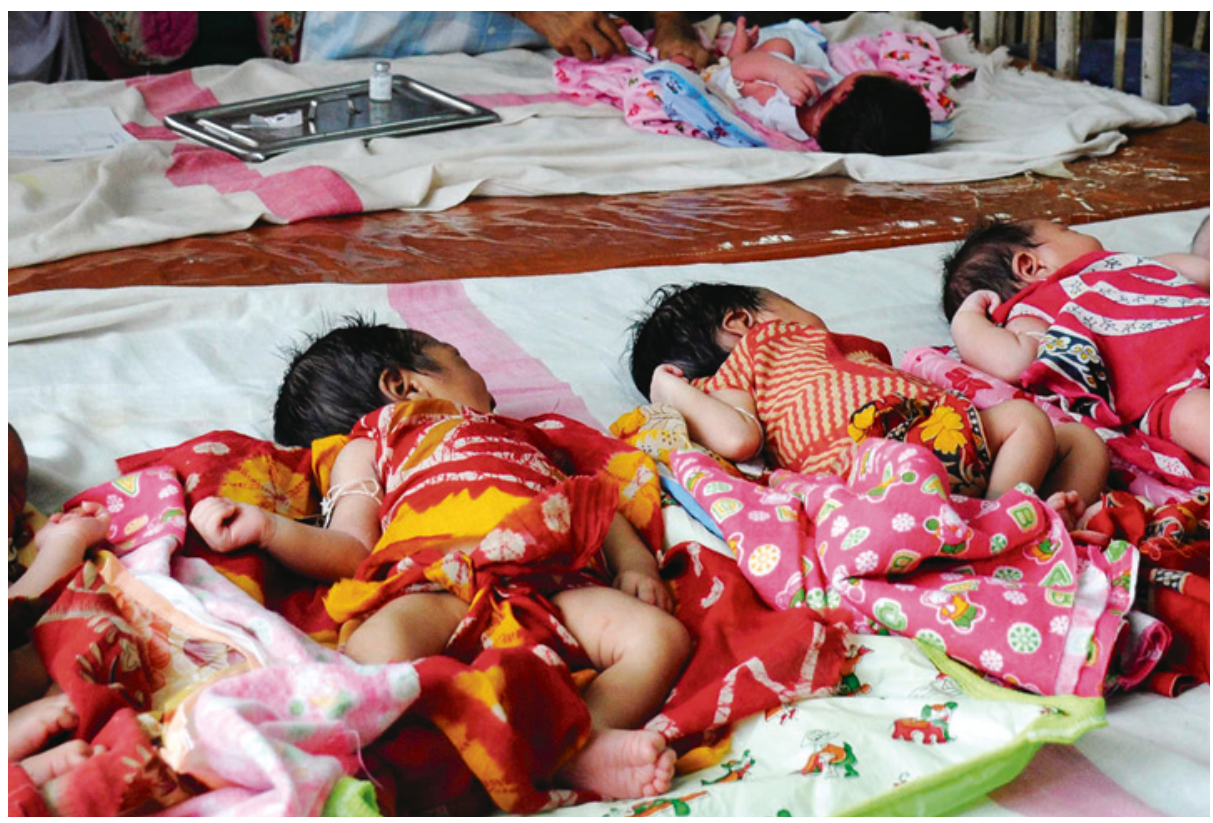

Illustrasjonsfoto: Arindam Dey/Scanpix

I lav- og mellominntektsland blir A-vitamin gitt til barn i aldersgruppen 6-60 måneder, men hvorvidt også nyfødte har nytte av A-vitamintilskudd er uklart. The Lancet publiserte nylig tre store studier med identisk utforming i forskjellige populasjoner, koordinert av Verdens helseorganisasjon. Studiene fra India, Tanzania og Ghana inkluderte hhv. 44984 nyfødte (1), 31999 nyfødte (2) og 22955 nyfødte (3). Alle tre studiene var randomiserte og dobbeltblinde, med sammenlikning av 50000 IE A-vitamin og placebo, gitt peroralt innen tre dager etter fødselen.

Den indiske studien viste redusert dødelighet ved 6-månedersalder for dem som hadde fått A-vitamin (relativ risiko (RR) 0,90; $95 \% \mathrm{KI} 0,81-1,00)$, mens det var trend $\mathrm{i}$ motsatt retning i de to afrikanske studiene (RR 1,10; $95 \%$ KI 0,95-1,26 i Tanzania, RR 1,12; $95 \%$ KI 0,95-1,33 i Ghana). Hos dem som hadde fått $\mathrm{A}$-vitamin ble det ikke notert alvorlige bivirkninger, bortsett fra økt forekomst av bukende fontanelle med uklar klinisk betydning.

Grunnen til at funnene varierte mellom studiene kan skyldes ernæringsstatus i studiepopulasjonene, spesielt A-vitaminmangel hos mødrene. Også tidligere studier har vist tendens til effekt av A-vitamin til nyfødte i Asia, men ikke i Afrika (4).

\section{Kristoffer Brodwall}

kristoffer.brodwall@gmail.com

Institutt for Global helse og samfunnsmedisin Universitetet i Bergen

\section{Litteratur}

1. Mazumder S, Taneja S, Bhatia K et al. Efficacy of early neonatal supplementation with vitamin A to reduce mortality in infancy in Haryana, India (Neovita): a randomised, double-blind, placebocontrolled trial. Lancet 2015; 385: 1333-42.

2. Masanja H, Emily R, Muhihi a et al. Effect of neonatal vitamin A supplementation on mortality in infancy: A randomized controlled trial in Tanzania. Lancet 2015; 385: 1324-32.

3. Edmond KM, Newton S, Shannon C et al. Effect of early neonatal vitamin A supplementation on mortality during infancy in Ghana (Neovita): a randomised, double-blind, placebo-controlled trial. Lancet 2015; 385: 1315-23.

4. Haider BA, Bhutta ZA. Neonatal vitamin A supplementation: time to move on. Lancet 2015; 385: $1268-71$ 